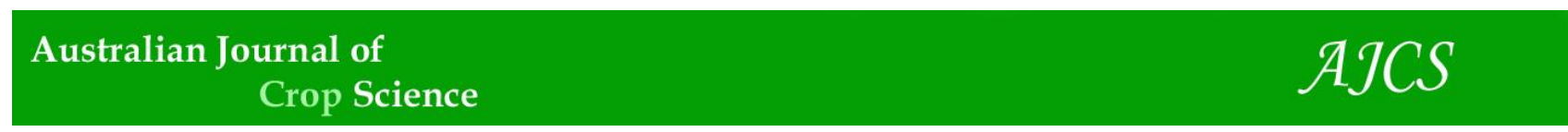

AJCS 14(03):524-530 (2020)

ISSN:1835-2707

doi: 10.21475/ajcs.20.14.03.p2213

\title{
Drying effect on physical and physicochemical properties and bioactive compounds of kiwifruit powder
}

\author{
Inacia dos Santos Moreira ${ }^{1}$, Wilton Pereira da Silva ${ }^{1}$, Josivanda Palmeira Gomes ${ }^{1}$, Deise Souza de \\ Castro ${ }^{1}$, Luzia Márcia de Melo Silva ${ }^{2}$, Francinalva Cordeiro de Sousa ${ }^{2}$, Jacinete Pereira Lima ${ }^{1}$, Cleide Maria \\ D. P. S. e Silva ${ }^{1}$, Jemima Ferreira Lisbôa ${ }^{1}$ and Henrique Valentim Moura ${ }^{1}$
}

\author{
${ }^{1}$ Federal University of Campina Grande, Campus I, PB, Brazil \\ ${ }^{2}$ Federal institute of education, Science, and technology of Alagoas, Campus Murici, Murici, AL, Brazil
}

*Corresponding author: inaciamoreira@ymail.com; https://orcid.org/0000-0002-7855-1895

\section{Abstract}

This study aimed to evaluate the effect of convective drying at different temperatures on the physical and chemical properties of kiwifruit powder. Circular kiwi slices were cut with thickness of $5.0 \mathrm{~mm}$ and subjected to different drying air temperatures (50, 60, 70 and $80 \stackrel{\circ}{\circ}$ ). After drying, the slices were ground to obtain the powder and characterized for the physical parameters, physicochemical parameters and bioactive compounds. The powders were characterized for physical and physicochemical attributes and bioactive compounds. The experimental design was completely randomized, with three replicates, and the data were subjected to analysis of variance by $\mathrm{F}$ test and to Tukey test at 0.05 probability level. Kiwifruit powders obtained by convective drying at 50, 60, 70 and $80 \stackrel{\circ}{\circ}$ were classified as non-hygroscopic, showing good flowability and low cohesiveness. Kiwifruit

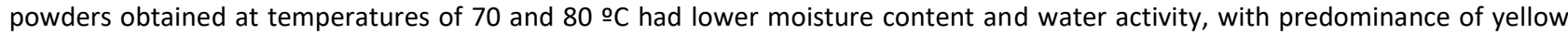
intensity over red intensity, which influenced their final color according to the drying air temperature. Powders obtained at the four drying temperatures showed significant amounts of bioactive compounds; thus, they can be consumed in powder and used in the preparation of food products. However, samples dehydrated at temperature of $70 \stackrel{\circ}{ } \mathrm{C}$ had higher contents of phenolic compounds compared to the others.

Keywords: Actinidia deliciosa, Bioactive compounds, Convective drying, food preservation and physicochemical analyses. Abbreviations: Y_Yield; MC_Moisture Content; W_Wettability, H_Hygroscopicity, $\rho_{a \_}$Apparent Density, $\rho_{a-}$ Compact Density, Cl_Compressibility Index, HR_Hausner ratio, $A_{w}$ Water activity, SS_soluble solids, TA_Titratable acidity, L*_Lightness, a*_Red, b*_Yellow, C*_Chromaticity, $\mathrm{H}^{\circ}$ _Hue angle, Vit C_Vitamin C, PC_Phenolic compounds, Fla_Flavonoids, TChl_Total Chlorophyll and TCar_Total Carotenoids.

\section{Introduction}

Kiwifruit (Actinidia deliciosa) is a plant belonging to the Actinidiaceae family and is characterized by fleshy, branched roots which tend to distribute in the upper substrate of the soil. It has a flexible stem with tendrils when young and, as the plant becomes adult, the lignified stems become woody and resistant. Its branches grow rapidly and may reach 6 to 8 meters within one year (Saquet and Brackman, 1995).

Kiwifruits are classified as climacteric fruits, since they ripe in response to ethylene (Whittaker et al., 1997). These fruits have an oval, spherical or elongated shape depending on the cultivar. Their appearance and nutritional values are usually influenced by the pigments and vitamins present in the fruit, where the taste is primarily influenced by acidity, sweetness and volatiles (Pal et al., 2015).

Kiwifruit contains a large amount of vitamins and minerals, and may have double the vitamin $C$ content of an orange (Heiffig et al., 2005). It has high contents of bioactive compounds, such as ascorbic acid, extractable polyphenols, flavonoids, carotenoids, among others (Bursal and Gulçin, 2011).

Usually consumed in the form of fresh fruits, kiwifruit is also used in the manufacture of products such as jellies, candies, jams, juices and beverages, among others. The limitation to its consumption is associated with the short shelf life due to the large amount of water in its composition, which facilitates rapid biochemical and microbiological transformations of the fresh product. Thus, kiwifruit drying constitutes one of the alternatives for its commercialization and can even improve some of its characteristics, since water activity decreases in the product, reducing degradation reactions (Doymaz and Pala, 2003; Simal et al., 2005). In addition, powder products, with long shelf life and microbiological stability, can reduce costs with transportation and storage (Jinapong et al., 2008; Çalişkan et al, 2015).

Convective drying using hot air is the most used technique to produce dehydrated fruits and vegetables. However, many 
of their properties are affected by the drying conditions, so studies on the physical and chemical quality of these products are required, in order to minimize possible losses of quality. According to Çalişkan et al (2015), the properties of food powders such as bulk density, hygroscopicity, degree of caking, dispersibility, wettability, solubility, particle size, and size distribution are useful for design and control of processing, handling, storage operations, and product quality control. Properties of powder products are usually studied in two groups, particle properties (particle size, shape, distribution, density and morphological properties) and bulk properties (bulk density, wettability, solubility, porosity, cohesiveness and flowability).

This study aimed to produce kiwifruit (Hayward variety) powder, which can be used as an alternative to manufacture several products, and obtain a product with high nutritional value, long durability, easy to be transported and a food additive. Besides the objectives mentioned, this study aimed to evaluate the effect of convective drying at different

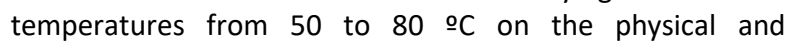
physicochemical properties and bioactive compounds of kiwifruit powder.

\section{Results and discussion}

\section{Physical analysis of kiwifruit powder}

Table 1 shows the physical parameters of kiwifruit powders obtained by convective drying at $50,60,70$ and 80 ㅇ. Kiwifruit yield values were similar for the temperatures used, varying from 16.12 to $16.69 \%$ for 50 and $80{ }^{\circ} \mathrm{C}$, respectively.

Wettability increased significantly $(p \leq 0.05)$ with increasing drying temperature, from 0.04 to $0.25 \mathrm{~g} / \mathrm{s}$ at the temperatures of 50 and $80 \stackrel{\circ}{ }$, respectively, meaning that the time required for complete disappearance of the powder on the surface of the liquid at rest decreased with the increase of temperature. Silva et al. (2018) reported that this behavior may be associated with the moisture content of the samples, since the lower the value, the easier the penetration of water, increasing the reconstitution capacity. Gomes et al. (2017), studying the physical characterization of West Indian cherry powder, observed that the powder obtained at 80 o $C$ required a longer time to submerge,

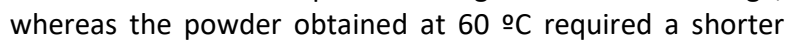
time of wettability.

There was an increase in the values of hygroscopicity with the increase of drying temperature to obtain kiwifruit powder. Kiwifruit powders obtained at different drying temperatures showed hygroscopicity values from $1.47 \%$ (50 ${ }^{\circ} \mathrm{C}$ ) to $2.12 \%\left(80{ }^{\circ} \mathrm{C}\right)$. According to the classification of GEA (2010) for serum powder, which can be applied to other dehydrated products, powders with hygroscopicity $<10 \%$ are classified as non-hygroscopic, 10.1 to $15 \%$ as slightly hygroscopic, 15.1 to $20 \%$ as hygroscopic, 20.1 to $25 \%$ as very hygroscopic, and $>25 \%$ as extremely hygroscopic. Thus, kiwifruit powders are classified as non-hygroscopic.

According to Table 1, $\rho_{a}$ decreased significantly with the increase in drying temperature, and there was no statistical difference between powders obtained at 70 and $80{ }^{\circ} \mathrm{C}$, varying from $0.49\left(60^{\circ} \mathrm{C}\right)$ to $0.68 \mathrm{~g} / \mathrm{mL}\left(50^{\circ} \mathrm{C}\right)$. Similar results were reported by Medeiros and Lannes (2010), who evaluated the physical properties of cocoa powder substitutes and found density values from 0.49 and 0.69 $\mathrm{g} / \mathrm{mL}$. Different results were reported by Gomes et al. (2017) for West Indian cherry powder, in which this parameter tended to increase as the drying temperature increased. It is worth pointing out that the analysis of apparent density is important because it particularly affects the packaging cost and industrial projects.

It was observed that $\rho_{c}$ values in kiwifruit powder samples were significantly affected by the drying temperatures used, and there was no defined behavior with the increase of temperature. The values varied from $0.54 \mathrm{~g} / \mathrm{mL}\left(60{ }^{\circ} \mathrm{C}\right)$ to $0.69 \mathrm{~g} / \mathrm{mL}\left(50^{\circ} \mathrm{C}\right)$. Similar results were reported by Lavoyer (2012), who dried green coconut in spouted bed dryer and observed compact density values between 0.59 and 0.63 $\mathrm{g} / \mathrm{mL}$. Gomes et al. (2017), studying West Indian cherry powder, reported values of $0.177,0.258$ and $0.284 \mathrm{~g} / \mathrm{cm}^{3}$ for the temperatures of 60,70 and $80{ }^{\circ} \mathrm{C}$, respectively, observing a trend of increment as the drying temperature increased.

The compressibility index $(\mathrm{Cl})$ increased significantly $(\mathrm{p} \leq 0.05)$ with the increment in drying temperature, varying from 5 to $10 \%$ for the temperatures of 50 and $80^{\circ} \mathrm{C}$, respectively. $\mathrm{Cl}$ is related to the capacity for packaging of the powder. According to Santhalakshmy et al. (2015), Cl values between 15 and $20 \%$ indicate good flowability; between $20-35 \%$ poor flowability; $35-45 \%$ bad flowability; and $\mathrm{Cl}$ higher than $45 \%$ indicate very bad flowability. According to this classification, kiwifruit powder dehydrated at $80^{\circ} \mathrm{C}$ has good flowability. Hausner ratio (HR) increased significantly $(p \leq 0.05)$ with increasing drying temperature, and there was no statistical difference between powders produced at temperatures of 60 and $70{ }^{\circ} \mathrm{C}$. Santhalakshmy et al. (2015) reported that Hausner ratio assesses the cohesiveness of the material and values below 1.2 are classified as low cohesiveness, between 1.2 and 1.4 as intermediate cohesiveness and $\mathrm{HR}>1.4$ indicates high cohesiveness. According to this classification, all kiwifruit powder samples showed low cohesiveness.

The results of the colorimetric analysis of kiwifruit powders obtained at different drying temperatures are presented in Table 2. Table 2 shows that the drying temperatures had significant effect $(p \leq 0.05)$ on the color coordinates $\left(L^{*}, a^{*}\right.$, $b^{*}, c^{*}$ and $\mathrm{H}^{\circ}$ ) of kiwifruit powder. The coordinate $\mathrm{L}^{*}$ (lightness), which in a range from 0 to 100 varies from black (0) to white (100), differed significantly between the drying temperatures used. According to Table 2, lightness increased significantly $(p \leq 0.05)$ with increasing drying temperatures. This value varied from $31.37\left(50^{\circ} \mathrm{C}\right)$ to $45\left(80^{\circ} \mathrm{C}\right)$, indicating that the kiwifruit sample when dried at $50{ }^{\circ} \mathrm{C}$ showed a darker color, whereas the sample dried at 80 으 showed a lighter color, as can be observed in Figure 1. It was observed that the degradation of lightness was significantly affected by the drying temperature compared to the drying time, which may be related to the time/temperature binomial, i.e., 5-mm-thick kiwifruit slices when dehydrated at $50 \stackrel{\circ}{\circ}$ to obtain the powder, for requiring the longest drying time (33 h), obtained the lowest value of lightness, 31.37. By contrast, when the temperature of $80 \stackrel{\circ}{ } \mathrm{C}$ was used, despite being a high temperature, it led to the shortest drying time $(9 \mathrm{~h})$ and consequently the highest values of lightness, 45 . The parameter $a^{*}$ (Table 2$)$ significantly differed $(p \leq 0.05$ ) between the powders obtained at different drying temperatures, but there was no defined pattern, as evidenced in the powder obtained at the temperature of 60 
으, which had the lowest value of this parameter $\left(a^{*}=7.61\right)$. The temperature of $50{ }^{\circ} \mathrm{C}$ led to $a^{*}$ value of 9.21 , while the powder dehydrated at $80 \stackrel{\circ}{ } \mathrm{C}$ had a* value of 10.41 . Since the parameter $a^{*}$ varies from red $(+a)$ to green $(-a)$, the powders exhibited a color closer to red, more intense in the powder produced at temperature of $80 \stackrel{\circ}{\circ}$. Increase in $a^{*}$ values indicates intensification of red color, due to the formation of dark-colored compounds (Reis et al., 2006).

Table 2 shows that the increase in drying temperature had a significant influence $(p \leq 0.05)$ on $b^{*}$ values, which increased as the drying temperature increased, and there was no statistical difference between powders obtained at temperatures of 70 and $80^{\circ} \mathrm{C}$. It should be pointed out that the parameter $b^{*}$ indicates hues from yellow $(+b)$ to blue $(-$ b), so the color of the analyzed samples tended to yellow, with values between $27.23\left(50{ }^{\circ} \mathrm{C}\right)$ and $35.16\left(80^{\circ} \mathrm{C}\right)$.

Yellow color prevailed over the red color in the kiwifruit powders, and the drying air temperature exerted an important influence on their final color. By comparing the results shown in Table 2 to those of Figure 1, it can be observed that the temperature of $50 \stackrel{\circ}{ } \mathrm{C}$ caused darkening in the kiwifruit powders.

Color saturation is represented by the parameter $C^{*}$, which indicates the purity or intensity of the color compared to white, determined by the coordinates $a^{*}$ and $b^{*}$. Chromaticity $\left(C^{*}\right)$ increased significantly $(p \leq 0.05)$ as the drying temperatures increased, with values between 28.74 and 36.37 for powders obtained at temperatures of 50 and $80 \stackrel{\circ}{ } \mathrm{C}$, respectively.

The hue angles $\left(\mathrm{H}^{\circ}\right)$ of the powders differed significantly $(p \leq 0.05)$ and no statistical difference was found between powders obtained at temperatures of 60 and $70{ }^{\circ} \mathrm{C}$. According to the values of hue angle, which indicates the hue of the sample, there was a reduction in the hue of the powder obtained at temperature of $80 \stackrel{\circ}{\circ}$ compared to those obtained at 60 and $70^{\circ} \mathrm{C}$.

\section{Physicochemical analysis of kiwifruit powder}

The results of chemical characterization of the kiwifruit powders obtained by convective drying at $50,60,70$ and 80 oC are presented in Table 3. According to Park and Antônio (2006), moisture content determination is fundamental in the drying process and is related to stability, quality and composition of the product, being able to affect all the steps from its processing and manufacture of derivatives to its storage, for being the main factor in biological processes. As demonstrated in Table 3, moisture content decreased significantly $(p \leq 0.05)$ as the drying temperature increased, and there was no statistical difference between the powders obtained at temperatures of 70 and $80{ }^{\circ} \mathrm{C}$. Moisture contents ranged between 15.29 and $10.27 \%$, for the temperatures of 50 and $80^{\circ} \mathrm{C}$, respectively. Similar values were reported by Santos et al (2015), who found moisture contents from 16.55 to $12.37 \%$ in cashew pulp powder obtained spouted bed drying, for temperatures of 50 and 70 ${ }^{\circ} \mathrm{C}$, respectively. Higher values than those found in the present study have been reported by other authors. Santos et al. (2010) found moisture content of $21.75 \%$ in dehydrated 'Isabel' grape.

Ferrari et al. (2012) reported that the use of higher temperatures causes higher rate of heat transfer to the particles, which leads to higher water evaporation from the product, resulting in powders with lower moisture contents, a phenomenon observed in the kiwifruit powders.

According to Table 3 , the water activity $\left(A_{w}\right)$ of kiwifruit powders decreased significantly $(p \leq 0.05)$ with the increase in drying temperature and there was no statistical difference between powders produced at temperatures of 70 and 80

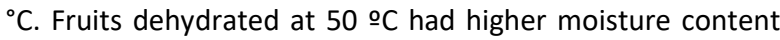
and consequently higher $A_{w}$ value (Table 3 ). The values found in the present study are consistent with those reported by Ferrari et al. (2012) and Santos et al. (2015), who studied the drying of blackberry and cashew pulps, respectively.

According to Guimarães and Silva (2008), water activity values for dry fruits may vary from 0.51 to 0.89 . In the present study, water activity values in the samples were 0.22 to $0.30 \%$ lower than those reported by these authors.

The values obtained for kiwifruit powder were within the range established for dried and microbiologically stable foods, water activity lower than 0.6 and moisture content lower than $25 \%$, a range considered as minimal for microorganism development (Gava et al., 2009).

Ash content was influenced by the drying temperatures. There was a concentration in the ash contents of powders dried at temperatures from 50 to 70 으, with a reduction for the powder obtained at $80 \stackrel{\circ}{ } \mathrm{C}$. It is worth mentioning that higher ash content provides higher contents of mineral salts. It was possible to observe in Table 3 that the contents of soluble solids were significantly different $(p \leq 0.05)$ between the powders obtained at different drying temperatures. The highest value found was 52.24 oBrix, at the temperature of $60 \stackrel{\circ}{ }$, which differed from the others.

Titratable acidity was influenced by drying temperature, but there was no defined pattern. Kiwifruit powder obtained at temperature of $60{ }^{\circ} \mathrm{C}$ had the highest titratable acidity (6.64\%), whereas the powder obtained by drying at $80{ }^{\circ} \mathrm{C}$ showed the lowest value (5.37\%). Castilho et al. (2014), working with peel flour of green bananas, cv. 'Maçã' and 'Prata', reported values of 5.13 and $5.42 \mathrm{~g} / 100 \mathrm{~g}$, respectively.

According to Table 3 , the $\mathrm{pH}$ values of kiwifruit powders varied between $3.40\left(50^{\circ} \mathrm{C}\right)$ and $2.96\left(80^{\circ} \mathrm{C}\right)$. The $\mathrm{pH}$ values found in kiwifruit powders dehydrated at the four drying temperatures indicate an acid powder, since they were lower than 4.5, according to the classification of Baruffaldi and Oliveira (1998). The acid concentration required to modify the $\mathrm{pH}$ value in foods depends on the contents of soluble solids, proteins and salts, on the buffering capacity of these components and on the degree of ionization of the acid (McCarthy et al., 1991).

According to Vasconcelos and Melo Filho (2010), foods are classified for acidity according to $\mathrm{pH}$ in the following manner: low-acidity foods ( $\mathrm{pH}>4.5)$ and acid foods $(\mathrm{pH}<4.5)$. According to this classification, kiwifruit powders obtained at the four temperatures are considered as acid foods.

\section{Bioactive compounds analysis of kiwifruit powder}

Table 4 presents the results of the bioactive compounds for kiwifruit powders dehydrated by oven drying at the studied temperatures. 
Table 1. Physical characterization of kiwifruit powders obtained by convective drying at 50,60, 70 and 80 ㅇ.

\begin{tabular}{llllllll}
\hline \multirow{2}{*}{$\mathrm{T}(\mathrm{o} \mathrm{C})$} & \multicolumn{7}{c}{ Characteristics evaluated } \\
\cline { 2 - 7 } & $\mathrm{Y}(\%)$ & $\begin{array}{l}\mathrm{W} \\
(\mathrm{g} / \mathrm{s})\end{array}$ & $\begin{array}{l}\mathrm{H} \\
(\%)\end{array}$ & $\begin{array}{l}\rho_{\mathrm{a}} \\
(\mathrm{g} / \mathrm{mL})\end{array}$ & $\begin{array}{l}\rho_{\mathrm{c}} \\
(\mathrm{g} / \mathrm{mL})\end{array}$ & $\begin{array}{l}\mathrm{Cl} \\
(\%)\end{array}$ & $\mathrm{HR}$ \\
\hline 50 & 16.12 & $0.04 \mathrm{~d}$ & $1.47 \mathrm{c}$ & $0.68 \mathrm{a}$ & $0.69 \mathrm{a}$ & $5.00 \mathrm{~d}$ & $1.05 \mathrm{c}$ \\
60 & 16.14 & $0.10 \mathrm{c}$ & $1.77 \mathrm{~b}$ & $0.49 \mathrm{c}$ & $0.54 \mathrm{~d}$ & $9.50 \mathrm{~b}$ & $1.09 \mathrm{~b}$ \\
70 & 16.18 & $0.17 \mathrm{~b}$ & $1.83 \mathrm{~b}$ & $0.52 \mathrm{~b}$ & $0.57 \mathrm{c}$ & $7.78 \mathrm{c}$ & $1.08 \mathrm{~b}$ \\
80 & 16.69 & $0.25 \mathrm{a}$ & $2.12 \mathrm{a}$ & $0.52 \mathrm{~b}$ & $0.61 \mathrm{~b}$ & $15.00 \mathrm{a}$ & $1.17 \mathrm{a}$ \\
\hline Mean & & 0.14 & 1.80 & 0.55 & 0.60 & 9.32 & 1.10 \\
CV (\%) & & 0.53 & 3.20 & 1.31 & 1.11 & 8.31 & 0.95 \\
\hline
\end{tabular}

Y_Yield; W_Wettability, H_Hygroscopicity, $\rho_{\mathrm{a}}$ Apparent Density, $\rho_{\mathrm{c}}$ Compact Density, Cl_Compressibility Index and HR_Hausner Ratio. Means followed by the same letter in the column do not differ by Tukey's test at $5 \%$ probability level.

(a)

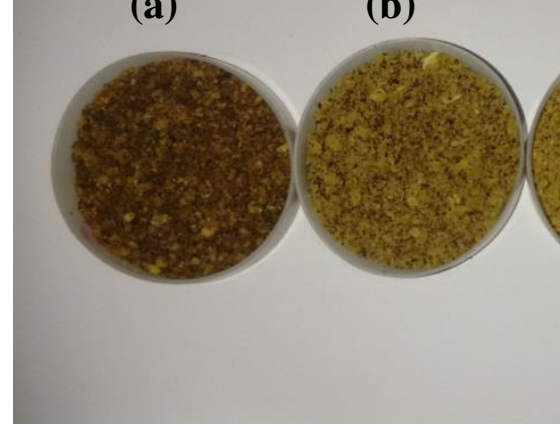

(c)

(d)

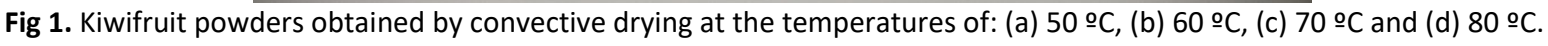

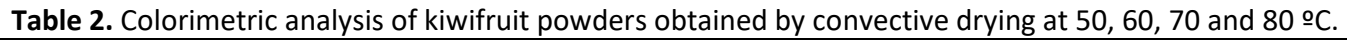

\begin{tabular}{llllll}
\hline $\mathbf{T}$ & \multicolumn{5}{c}{ Characteristics evaluated } \\
\cline { 2 - 6 } (oC) & $\mathrm{L}^{*}$ & $\mathrm{a}^{*}$ & $\mathrm{~b}^{*}$ & $\mathrm{C}^{*}$ & $\mathrm{H}^{\circ}$ \\
\hline 50 & $31.37 \mathrm{~d}$ & $9.21 \mathrm{~b}$ & $27.23 \mathrm{c}$ & $28.74 \mathrm{~d}$ & $71.30 \mathrm{c}$ \\
60 & $40.10 \mathrm{C}$ & $7.61 \mathrm{~d}$ & $31.37 \mathrm{~b}$ & $32.28 \mathrm{c}$ & $76.36 \mathrm{a}$ \\
70 & $44.19 \mathrm{~b}$ & $8.17 \mathrm{c}$ & $34.90 \mathrm{a}$ & $35.85 \mathrm{~b}$ & $76.83 \mathrm{a}$ \\
80 & $45.00 \mathrm{a}$ & $10.41 \mathrm{a}$ & $35.16 \mathrm{a}$ & $36.37 \mathrm{a}$ & $73.50 \mathrm{~b}$ \\
\hline Mean & 40.17 & 8.85 & 32.17 & 33.39 & 74.50 \\
$\mathrm{CV}(\%)$ & 0.17 & 0.69 & 0.59 & 0.51 & 0.26 \\
\hline \multicolumn{5}{l}{ Means followed by the same letter in the column do not differ by Tukey's test at 5\% probability level. }
\end{tabular}

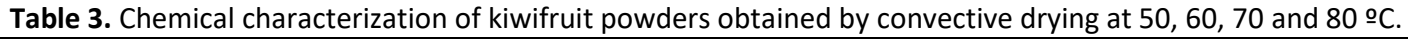

\begin{tabular}{lllllll}
\hline \begin{tabular}{l}
$\mathrm{T}($ oC) \\
\cline { 2 - 7 }
\end{tabular} & $\begin{array}{l}\mathrm{MC} \\
\text { (\% w.b.) }\end{array}$ & $\mathrm{A}_{\mathrm{w}}$ & $\begin{array}{l}\text { Ashes } \\
\text { (\%) }\end{array}$ & $\begin{array}{l}\text { SS } \\
\text { (oBrix) }\end{array}$ & $\begin{array}{l}\text { TA } \\
\text { (\%Citric acid) }\end{array}$ & $\mathrm{pH}$ \\
\hline 50 & $15.29 \mathrm{a}$ & $0.30 \mathrm{a}$ & $3.89 \mathrm{c}$ & $50.44 \mathrm{c}$ & $6.31 \mathrm{~b}$ & 3.40 \\
60 & $13.54 \mathrm{~b}$ & $0.23 \mathrm{~b}$ & $4.20 \mathrm{~b}$ & $52.24 \mathrm{a}$ & $6.64 \mathrm{a}$ & 3.13 \\
70 & $10.92 \mathrm{c}$ & $0.22 \mathrm{c}$ & $4.29 \mathrm{a}$ & $51.31 \mathrm{~b}$ & $5.99 \mathrm{c}$ & 3.38 \\
80 & $10.27 \mathrm{c}$ & $0.22 \mathrm{c}$ & $3.56 \mathrm{~d}$ & $51.74 \mathrm{ab}$ & $5.37 \mathrm{~d}$ & 2.96 \\
Mean & 12.51 & 0.24 & 3.98 & 51.43 & 6.08 & 3.21 \\
CV(\%) & 2.17 & 1.35 & 0.66 & 0.40 & 0.79 & 1.49 \\
\hline
\end{tabular}

MC_Moisture content, $A_{w \_}$Water activity, SS_Soluble Solids, TA_Titratable acidity. Means followed by the same letter in the column do not differ by Tukey's test at $5 \%$ probability level.

Table 4. Characterization of bioactive compounds of kiwifruit powders obtained by convective drying at 50, 60, 70 and 80 ㄷ.

\begin{tabular}{llllll}
\hline & \multicolumn{5}{c}{ Characteristics evaluated } \\
\cline { 2 - 5 } $\mathrm{T}($ o $\mathrm{C})$ & Vit C (mg/100g) & $\mathrm{PC}(\mathrm{mg} / 100 \mathrm{~g})$ & Fla $(\mathrm{mg} / 100 \mathrm{~g})$ & $\mathrm{TChl}(\mathrm{mg} / 100 \mathrm{~g})$ & TCar $(\mathrm{mg} / 100 \mathrm{~g})$ \\
\hline 50 & $89.05 \mathrm{a}$ & $542.92 \mathrm{c}$ & $2.90 \mathrm{~d}$ & $3.59 \mathrm{c}$ & $2.27 \mathrm{c}$ \\
60 & $82.56 \mathrm{c}$ & $534.92 \mathrm{~d}$ & $3.98 \mathrm{c}$ & $2.99 \mathrm{~d}$ & $2.13 \mathrm{~d}$ \\
70 & $85.79 \mathrm{~b}$ & $609.30 \mathrm{a}$ & $4.10 \mathrm{~b}$ & $5.35 \mathrm{a}$ & $4.11 \mathrm{~b}$ \\
80 & $86.43 \mathrm{~b}$ & $559.67 \mathrm{~b}$ & $4.81 \mathrm{a}$ & $4.84 \mathrm{~b}$ & $5.39 \mathrm{a}$ \\
\hline Mean & 85.96 & 561.70 & 3.95 & 4.19 & 3.48 \\
CV(\%) & 1.09 & 0.35 & 0.22 & 0.72 & 0.32 \\
\hline Vit C_Vitamin C, PC_Phenolic Compounds, Fla_Flavonoids, TChI_Total Chlorophyll and TCar_Total Carotenoids. Means followed by the same letter in the column do not differ by Tukey
\end{tabular}
test at $5 \%$ probability level. 
The mean contents of vitamin $\mathrm{C}$ in kiwifruit powders obtained at 50,60 and $70{ }^{\circ} \mathrm{C}$ differed statistically, but there were no significant differences between the values relative to the temperatures of 70 and $80^{\circ} \mathrm{C}$. There was no defined pattern between the drying temperatures, with values between $82.56\left(60^{\circ} \mathrm{C}\right)$ and $89.05\left(50^{\circ} \mathrm{C}\right)$.

The contents of phenolic compounds in kiwifruit powders differed statistically between the temperatures used, varying from 534.92 to $609.30 \mathrm{mg} / 100 \mathrm{~g}$ (Table 4). The highest content of phenolic compounds was observed in kiwifruit powder obtained at $70 \stackrel{\circ}{ } \mathrm{C}$, whereas the lowest content was found in the powder obtained at $60 \stackrel{\circ}{ } \mathrm{C}$.

The contents of flavonoids increased significantly $(p \leq 0.05)$ as the drying temperature increased (Table 4 ), ranging from $2.90 \mathrm{mg} / 100 \mathrm{~g}\left(50{ }^{\circ} \mathrm{C}\right)$ to $4.81 \mathrm{mg} / 100 \mathrm{~g}\left(80^{\circ} \mathrm{C}\right)$.

For total chlorophyll, statistical difference $(p \leq 0.05)$ was observed between the drying temperatures used, with values ranging between $2.99 \mathrm{mg} / 100 \mathrm{~g}(60 \mathrm{\circ} \mathrm{C}$ ) and 5.35 $\mathrm{mg} / 100 \mathrm{~g}\left(70^{\circ} \mathrm{C}\right)$.

According to Table 4, the contents of total carotenoids were influenced by the drying temperatures, where the highest values were found in the powder dehydrated at $80{ }^{\circ} \mathrm{C}$ (5.39 $\mathrm{mg} / 100 \mathrm{~g}$ ) and the lowest values were observed at temperature of $60^{\circ} \mathrm{C}(2.13 \mathrm{mg} / 100 \mathrm{~g})$.

\section{Materials and Methods}

\section{Acquisition and selection of fruits}

Kiwifruits, Hayward variety, at commercial maturity stage, were purchased at the Paraíba's Company of Supply and Agricultural Services (EMPASA) in the city of Campina Grande - PB, Brazil. After acquisition, the fruits were taken to the Laboratory of Processing and Storage of Agricultural Products (LAPPA) belonging to the Federal University of Campina Grande (UFCG).

After selection, the fruits were washed with $1 \%$ neutral detergent, rinsed in running water, sanitized with a $15 \%$ sodium hypochlorite solution for $5 \mathrm{~min}$, manually peeled with stainless-steel knives, and cut into circular slices of about $49 \mathrm{~mm}$ diameter and $5 \mathrm{~mm}$ thickness. Then, the slices were dried in a forced air circulation oven (Marconi brand, MA 035/3IN250 model), set to operate at temperatures of $50,60,70$ and 80 ㅇ. The experiments were conducted in triplicate and the moisture content was determined by the gravimetric method, weighing the slices on analytical scale until reaching equilibrium moisture content. After drying, kiwifruit slices were subjected to grinding. The dehydrated product was removed from the trays, ground and homogenized in a domestic food processor to obtain the pulverized product (kiwifruit powder), and a grinding time of 5 minutes was fixed for each experiment.

\section{Physical analysis}

Kiwifruit powder was subjected to the following physical analyses: wettability, hygroscopicity, apparent density, compact density, compressibility index, Hausner ratio and color.

Wettability was determined according to the method proposed by Ceballos et al. (2012). This method consists in gently placing $1 \mathrm{~g}$ of sample in $100 \mathrm{~mL}$ of distilled water at 25 oC and visually determining the time required for all particles to become wet, using a stopwatch. Wettability was calculated according to Equation 1:

$W=\frac{\eta}{t}$,

Where: $W$ - wettability; $\eta$ - sample mass, g; $t$ - time, s.

Hygroscopicity was determined according to the method proposed by Goula and Adamopoulos (2010). Powder samples (approximately $1 \mathrm{~g}$ ) were weighed on glass capsules and placed in a hermetic container with a $\mathrm{NaCl}$-saturated solution (75.29\% relative humidity) at 25 oC for seven days. Subsequently, the powders were weighed and their hygroscopicity was determined using Equation 2:

$\mathrm{H}=\frac{X}{U * a} * 100$,

Where: $H$ - hygroscopicity (\%); $X$ - absorbed mass of water, $\mathrm{g} ; U$ - powder moisture content on dry basis, $\mathrm{g} . \mathrm{g}^{-1} ; a-$ sample mass, $\mathrm{g}$.

Apparent density was determined by weighing $6 \mathrm{~g}$ of kiwifruit powder in $10-\mathrm{mL}$ graduated cylinder, without compaction, to determine the total volume occupied by the solids (Eq. 3), following the method used by Souza et al. (2010). Apparent density was calculated using Equation 3:

$\rho_{a}=\frac{m_{s}}{V_{t}}$

Where: $\rho_{a}$ - apparent density; $m_{s}$ - mass of solids, g; $V_{t}$ total volume, $\mathrm{mL}$.

To determine the compact density, a $10-\mathrm{mL}$ graduated cylinder was filled with kiwifruit powder and manually tapped 50 times on the counter surface from a $10 \mathrm{~cm}$ height (Tonon et al., 2013). The mass contained in the cylinder was then weighed and compact density was calculated according to Equation 4:

$\rho_{c}=\frac{m_{s}}{V_{c}}$

Where: $\rho_{c}$-compact density; $m_{s}$ - mass of solids,

$\mathrm{g} ; V_{c}$ - volume of solids after compaction, $\mathrm{mL}$.

The compressibility index was calculated according to Equation 5:

$C I=\frac{\rho_{c-} \rho_{a}}{\rho_{c}} * 100$

Where: $C I$ - compressibility index; $\rho_{c}$ - compact density; $\rho_{a}$ - apparent density.

Hausner ratio was used to indirectly evaluate flow properties of the powders and was determined from the apparent density $\left(\rho_{\mathrm{a}}\right)$ and compact density $\left(\rho_{\mathrm{c}}\right)$, according to the methodology proposed by Hausner (1967), using Equation 6:

$H R=\frac{\rho_{c}}{\rho_{a}}$,

Where: $H R$ - Hausner ratio; $\rho_{c}$ - compact density; $\rho_{a}$ apparent density.

Color was determined by direct reading of kiwifruits using a MiniScan HunterLab XE Plus spectrophotometer, $4500 \mathrm{~L}$ model, with CIELAB color system. The device, equipped with $\mathrm{D} 65 / 10^{\circ}$ illuminant, was calibrated with standard black and white plates $(x=80.5, y=85.3, z=90.0)$, according to the manufacturer's instructions. The coordinates determined were: $L^{*}$, which represents lightness, the transition from black (0) to white (100); $a^{*}$, which represents the transition 
from green $\left(-a^{*}\right)$ to red $\left(+a^{*}\right)$; and $b^{*}$, the transition from blue $\left(-b^{*}\right)$ to yellow $\left(+b^{*}\right)$.

\section{Physicochemical analysis}

Kiwifruit powder samples were chemically characterized for the parameters: moisture content, water activity $\left(A_{w}\right)$, ashes, soluble solids, titratable acidity and $\mathrm{pH}$, according to the methodology described by the Instituto Adolfo Lutz (2008).

\section{Bioactive compounds analysis}

Kiwifruit powder samples were characterized for the parameters total ascorbic acid, phenolic compounds, flavonoids, total chlorophylls and carotenoids (bioactive compounds).

Ascorbic acid was determined according to the Instituto Adolfo Lutz (2008), by titration with 2,6dichlorophenolindophenol (DCPIP).

Phenolic compounds were determined using the FolinCiocalteau method described by Waterhouse (2006). The extracts were prepared by diluting $1 \mathrm{~g}$ of kiwifruit powder in $50 \mathrm{~mL}$ of distilled water, left at rest for 1 hour. A $250-\mu \mathrm{L}$ aliquot of the extract was transferred to a test tube, which received $1875 \mu \mathrm{L}$ of distilled water and $125 \mu \mathrm{L}$ of the FolinCiocalteau reagent. The mixture remained at rest for $5 \mathrm{~min}$ and, shortly after, $250 \mu \mathrm{L}$ of $20 \%$ sodium carbonate were added, followed by stirring and rest in water bath at $40{ }^{\circ} \mathrm{C}$ for $30 \mathrm{~min}$. The standard curve was prepared with gallic acid, and readings were taken in spectrophotometer at $765 \mathrm{~nm}$ wavelength. The result was expressed in $\mathrm{mg}$ of gallic acid/100 g of sample.

Total flavonoids were determined using the colorimetric method with aluminum chloride according to Woisky and Salatino (1998). In this method, a 5\% aluminum chloride solution was used. Readings were taken in spectrophotometer at $425 \mathrm{~nm}$ wavelength. The content of flavonoids was determined using a quercetin calibration curve within the interval from 4 to $12 \mu \mathrm{g} / \mathrm{mL}$. The results were expressed in $\mathrm{mg}$ of quercetin/100 $\mathrm{g}$ of sample.

Total chlorophylls and carotenoids $(\mathrm{mg} / 100 \mathrm{~g})$ were determined according to Lichtenthaler (1987) and calculated using Equations 7 and 8. Approximately $0.5 \mathrm{~g}$ of sample was macerated in mortar with $0.2 \mathrm{~g}$ of calcium carbonate $\left(\mathrm{CaCO}_{3}\right)$ and $10 \mathrm{~mL}$ of cold acetone $(80 \%)$ in dark environment. Then, the samples were centrifuged at $3000 \mathrm{rpm}$ for $10 \mathrm{~min}$, at 10 ${ }^{\circ} \mathrm{C}$, and the supernatants were read in spectrophotometer at wavelengths of 470,646 and $663 \mathrm{~nm}$.

Total chlorophyll $=\left[\frac{(17.3 * A b s 646+7.18 * A b s 663)}{\operatorname{mass}(\mathrm{g})}\right] * \frac{100}{1000}$

Carotenoids $=\left[\frac{(1000 * A b s 470-1.82 * C a-85.02 * C b)}{198}\right] * \frac{100}{1000}$

Where:

Abs = absorbance

$C a=\left[\frac{(12.21 * A b s 663-2.81 * A b s 646)}{\operatorname{mass}(g)}\right] * \frac{100}{1000}$

$C b=\left[\frac{(20.13 * A b s 646-5.03 * A b s 663)}{\operatorname{mass}(g)}\right] * \frac{100}{1000}$

\section{Statistical analysis}

Statistical analysis was conducted in a completely randomized design, with 3 replicates, and the data were subjected to analysis of variance (ANOVA) by $F$ test at 0.05 probability level.

\section{Conclusions}

Kiwifruit powders obtained by convective drying at 50,60 , 70 and $80 \stackrel{\circ}{ } \mathrm{C}$ are classified as non-hygroscopic, showing good flowability and low cohesiveness. At temperatures of 70 and $80 \stackrel{\circ}{ } \mathrm{C}$, the powders showed lower moisture content and water activity. Drying air temperature was a determinant factor influencing the final color of kiwifruit powders. In general, kiwifruit powders contain significant amounts of bioactive compounds, and highest content of phenolic compounds was obtained in the powder dehydrated at $70 \stackrel{\circ}{\circ}$.

\section{References}

Baruffaldi R, Oliveira MN (1998) Fundamentals of Food Technology. 1 ed. São Paulo: Ateneu.

Bursal E, Gülçin I (2011) Polyphenol contents and in vitro antioxidant activities of lyophilised aqueous extract of kiwifruit (Actinidia deliciosa). Food Research Int. 44:148158.

Çalişkan G, Ergün K, Dirim SN (2015) Freeze Drying of Kiwi (Actinidia deliciosa) Puree and the Powder Properties. Ital J Food Sci. 27:385-396.

Caparino OA, Tang J, Nindo $\mathrm{Cl}$, Sablani SS, Powers JR, Fellman JK (2012) Effect of drying methods on the physical properties and microstructures of mango (Philippine 'Carabao' var.) powder. J Food Eng. 111:135-148.

Castilho LG, Alcantara BM, Clemente E (2014) Development and physico-chemical analysis of the flour of the bark, the in natura bark and the green banana pulp of the cultivars apple and silver. E-xacta. 7:107-114.

Ceballos AM, Giraldo GI, Orrego CE (2012) Effect of freezing rate on quality parameters of freeze dried sour sop fruit pulp. J Food Eng. 111:360-365.

Doymaz I, Pala M (2003) The thin-layer drying characteristics of corn. J Food Eng. 60:125-130.

Ferrari CC, Ribeiro CP, Aguirre JM (2012) Blackberry pulp spray drying using maltodextrin as carrier agent. Brazilian J Food Technol. 15:157-165.

Gava AJ, Silva CAB, Frias JRG (2009) Food Technology

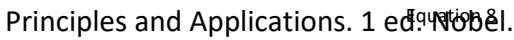

GEA Niro Research Laboratory. Gea Niro analytical methods 2010. Avaliable at: <http://www.niro.com/methods $>$. Access on: February 20, 2017.

Gomes LDBC, Almeida EM, Oliveira SN (2017) Kinetics of foam layer drying and physical characterization of acerola powder. Rev Brasil Agrotecnol. 7:178-184.

Goula AM, Adamopoulos KG (2010) A new technique for spray drying orange juice concentrate. Innovat Food Science Emerg Technol. 11:342-351.

Guimarães MM, Silva MS (2008) Nutritional value and chemical and physical characteristics of fruits (Byrsonima verbascifolia). Cienc e Tecnol de Alim. 28:817-821.

Hausner HH (1967) Friction conditions in a mass of metal powder. Powder Metall. 3:7-13. 
Heiffig LS, Aguila JS, Suguino, E, Scarpare Filho JA (2005) Kiwi: Alternative culture for small farms. Piracicaba: ESALQ - Divisão de Biblioteca e documentação, 45p. (Série produtor rural, $\left.n^{\circ} 27\right)$.

Instituto Adolfo Lutz (2008) Normas Analíticas do Instituto Adolfo Lutz: Métodos Químicos e Físicos para Análise de Alimentos. 4. ed. São Paulo: IAL.

Jinapong N, Suphantharika M, Jamnong P (2008) Production of instant soymilk powders by ultrafiltration, spray drying and fluidized bed agglomeration. Journal of Food Engineering. 84:194-205.

Lavoyer FCG (2012) Study of the drying of green coconut pulp in spruce bed and feasibility of its use in the industry. São José do Rio Preto, Brasil: Universidade Estadual Paulista, Dissertação.

Lichtenthaler HK (1987) Chlorophylls and carotenoids: pigments of photosynthetic biomembranes. Methods in Enzymology. 148: 350-382.

McCarthy MJ, Heil JR, Kruegermann C, Desvignes D (1991) Acid requirement for $\mathrm{pH}$ modification of processed foods. J Food Science. 56:973-976.

Medeiros ML, Lannes SCS (2010) Physical properties of cocoa substitutes. Cienc and Tecnol de Alim. 30:243-253.

Pal RS, Kumar VA, Arora S, Sharma AK, Kumar V, Agrawal S (2015) Physicochemical and antioxidant properties of kiwifruit as a function of cultivar and fruit harvested month. Braz Arch Biol Technol. 58:262-271.

Park KJ, Antonio GC (2006) Analysis of biological materials. Available <http://www.feagri.unicamp.br/ctea/manuais/analise_ma tbiologico.pdf $>$.Access on: February 20, 2018.

Reis RC, Ramos AM, Regazzi AJ, Minim VPR, Stringueta PC (2006) Almacenamiento de mango secado: análisis fisicoquímico, microbiológico, color y sensorial. Cienc y Tecnol Aliment. 5:214-225.

Santhalakshmy S, Bosco SJD, Francis S, Sabeena M (2015) Effect of inlet temperature on physicochemical properties of spray-dried jamun fruit juice powder. Powder Technol. 274:37-43.
Santos DC, Oliveira ENA, Martins JN, Rocha APT (2015) Secagem da polpa de caju em secador de leito de jorro. Rev Brasil Tecnol Agraind. 9:1875-1887.

Santos EHB, Azêvedo LC, Batista FPR, Lima MS, Azoubel PM (2010) Secagem e caracterização fisico-quimica da uva Isabel (Vitis labrusca). Available at: <http://connepi.ifal.edu.br/ocs/index.php/connepi/CONN EPI2010/paper/viewFile/245/199>. Access on: April 13, 2018.

Saquet AA, Brackman A (1995) A cultura do kiwi. Ciência Rural. 25:177-182.

Silva LMM, Almeida FAC, Sousa FC, Castro DS, Moreira IS, LIMA JP, NETO AF (2018) Chemical and physical characterization of peanut powder extracts. J Agric Science. 10:323-334.

Simal S, Femenia A, Garau MC, Rossell C (2005) Use of exponential Page's and diffusional models to simulate the drying kinetics of kiwi fruit. J Food Engin. 66:323-328.

Souza RLA, Oliveira LSC, Silva FLH, Amorim BC (2010) Caracterização da poligalacturonase produzida por fermentação semi-sólida utilizando-se resíduo do maracujá como substrato. Rev Bras Eng Agríc Amb. 14:987-992.

Tonon RV, Brabet C, Hubinger MD (2013) Aplicação da secagem por atomização para a obtenção de produtos funcionais com alto valor agregado a partir do açaí. Inclusão Social. 6:70-76.

Vasconcelos MAS, Melo Filho AB (2010) Técnico em alimentos: Conservação de alimentos. Escola Técnica Aberta do Brasil (e-Tec Brasil).

Waterhouse A (2006) Folin-ciocalteau micro method for total phenol in wine. American J Enol Vitic. 3-5.

Whittaker DJ, Smith GS, Gardner RC (1997) Expression of the ethylene biosynthetic genes in Actinidia chinensis fruit. Plant Molecular Biology. 4:45-55.

Woisky RG, Salatino A (1998) Analysis of propolis: some parameters and procedures for chemical quality control. J Apic Research. 37:99-105. 